\title{
Phlebotomist barbers and the Quixote
}

\author{
Los barberos flebotomianos y el Quijote
}

\begin{abstract}
Homage to Don Miguel Cervantes Saavedra on the 400th anniversary of his death

In the prolific literary work of Miguel de Cervantes Saavedra, who can be doubtlessly considered the Spanish language most transcendent author of all times, there are many references to health, sickness, surgical and medical treatments as well as dental references. This leads us to believe that Cervantes knew a lot more about medicine and dentistry than the habitual knowledge of his contemporary countrymen. This knowledge would place him as an author of great relevance for the knowledge of dental practices in the XVI century and beginning of the XVII century, a time when dentistry was still not regarded as an independent and structured profession. Treatment of dental afflictions was in the hands of surgeons and the so-called tooth puller phlebotomist barbers.
\end{abstract}

Martha Díaz Gómez*

\section{THE PHLEBOTOMIST BARBER TRADE}

Since the Middle Ages, in the whole of Europe, subjects dedicated to performing phlebotomies proliferated. These individuals performed phlebotomies as well as other surgical procedures such as lancing abscesses and performing tooth extractions. All of them performed these procedures without any kind of control or university preparation. In Spain, the trade of phlebotomist barber was regulated at the mid XV century. The Kings High Barbers "Barberos Mayores del Rey» were entrusted with drafting the trade's ordinances. Due to the great amount of subjects in the population requiring these services, the number of phlebotomist barbers increased; few of them complied with the ordinances. For all the aforementioned reasons, in 1500, Isabel and Fernando kings of Spain issued a disposition with the following directions: ${ }^{1}$

\footnotetext{
${ }^{1}$ Rocha Garfias Vanesa Pág. 72.

${ }^{2}$ Así se le llamaba al lugar en donde ejercían el oficio.
}

«We command that all High Examining Barbers, from this moment onwards, do not consent or grant leave for any barber or other person to set up shop for the purpose of bleeding, applying leeches or suctioning cups, pulling teeth or molars, without having been previously examined by our High Barbers...»

Those who passed obtained their "examination certificate", and had to show this document to relevant authorities in order to open their «barber's shop» (as the place where they practiced their trade was called). ${ }^{2}$

Some practiced at home, others set up shop in public places, or were even employed by noble and rich families; occasionally they were part of the king's payroll.

In 1557 a very transcendent event took place in the realm of dental endeavors: the publication of the first book written in Spanish dealing exclusively with afflictions of the mouth, their causes and treatments. The author was the physician Francisco Martinez del Castillo, who wrote this book prompted by his concern about the poor practice of surgeons and tooth puller phlebotomist barbers as well as rivalry existing among the aforementioned and surgeons possessing a university degree. Martinez del Castillo was an educated and learned physician. His good reputation earned him the nomination of physician of the mouth of king Phillip the Second of Spain. In his book, the author includes innovative concepts with respect to anatomy, tooth function, caries and periodontal diseases, prostheses, and surprisingly, ideas on prevention. The «Coloquio

\footnotetext{
* History Department, National School of Dentistry, National University of Mexico, UNAM.

(C) 2016 Universidad Nacional Autónoma de México, [Facultad de Odontología]. This is an open access article under the CC BY-NCND license (http://creativecommons.org/licenses/by-nc-nd/4.0/).
}

This article can be read in its full version in the following page: http://www.medigraphic.com/facultadodontologiaunam 
breve y compendio sobre la materia de la dentadura y la maravillosa obra de la boca» (Brief discussion and compendium on the subject of dentition and wondrous function of the mouth) bore great influence in Renaissance Spain. ${ }^{3}$

Many Miguel de Cervantes biographers believe he must have been aware of the content of such an important treatise ${ }^{4}$ since his intellectual pursuits were more than evident and the subject of the teeth interested him all his life.

\section{MIGUEL DE CERVANTES SAAVEDRA AND HIS DENTAL REFERENCES}

In all his literary production, Cervantes manifests his familiarity with the medical-surgical practice he experienced in his familial environment, since there is every reason to believe that his father, Rodrigo de Cervantes, dedicated a great part of his working life to the practice of surgery, specifically to treating dental problems.

In an important amount of writings of the so called "Cervantes Documentation» Don Rodrigo represents himself as a surgeon and physician; such is the case of the letter dated October $30^{\text {th }} 1565$, where he empowers his wife, Leonor de Cortinas, mother of the author, and his nephew Andres, to collect a debt, possibly contracted by work of the trade he performed. This sum should be received by his wife or nephew due to his own absence from the family home.

Don Miguel came from an «hidalgo» family (prominent); his maternal grandfather Don Juan Díaz de Torreblanca, was a professional surgeon, whilst, on this father's side of the family, don Juan de Cervantes was an educated and influential man, since he graduated in law studies and moved within a circle of lawyers, physicians, clergymen and university professors.

The family composed of Don Rodrigo de Cervantes and Doña Leonor de Cortinas lived in Alcala de Henares, where three daughters were born to them: Andrea, Luisa and Magdalena, as well as two sons: Miguel and Rodrigo. At 21, Miguel, along with his brother, enlisted in the army to leave for Naples, where both would embark in the galley «La Marquesa» which, as part of the Spanish Armada, very soon would take part in the battle of Lepanto, against the Ottoman fleet. At this age, Miguel de Cervantes had learned from his father all about the trade of barberbleeder-tooth-puller and, while in the ship, would have

\footnotetext{
${ }^{3}$ Esponda G, Víctor y Aguilar L, Lourdes Pág. 43-48.

${ }^{4}$ Antonio del Valle González Pág. 76.

${ }^{5}$ Receta.
}

contact with subjects devoted to treat sailors, soldiers and officials. It is understandable that Miguel de Cervantes would experience affinity for them. During the aforementioned battle, Miguel the Cervantes was wounded by an arquebus (musket) in the left arm. After victory, the Spanish fleet returned to Italian soil and Miguel was taken to a Hospital in Messina, where he remained for a year and a half due to the severity of the sustained wound.

During this time he established very close contact with physicians and surgeons, and could observe their work. In fact, the misadventures of the Cervantes brothers began upon their return to Spain, since during the journey from Naples to Spanish soil the ship was captured by pirates, who took the captives to Algeria. They remained five years in captivity, during which time the brothers unsuccessfully tried to escape in several instances. The years he remained in captivity were shared with other wretched people, among which was a doctor in philosophy called Sosa with whom Miguel developed a sincere friendship. In the meantime, his parents collected all the available funds in order to pay the ransom, they sold their meagre properties, and finally succeeded.

Upon his return to Spain, Miguel de Cervantes began to write and in his texts he mentions, for better or worse, the physicians he met in his wanderings. In the "Canto del Calíope» (Caliope's song) he names Doctors Campuzano, Vaca, Francisco Díaz and academic graduate Juan de Vergara, physician, surgeon and poet in the following octave:

...El alto ingenio y su valor declara un licenciado tan amigo vuestro cuanto ya sabéis que es Juan de Vergara, honra del siglo venturoso nuestro...

(High ingenuity and courage declare a professional who is such a great friend of ours whom you already know is called Vergara who is a credit to our blessed century)

In other occasions he proffers severe criticism, to physicians of poor practice whom he calls second rate physicians:

...Sólo los médicos nos pueden matar y nos matan sin temor y a pié quedo, sin desenvainar otra espada que la de un récipe... ${ }^{5}$

(Only physicians can kill us and they kill us without fear. And I remained on foot, drawing no other sword than a prescription.) 
In many instances he acknowledges the great value of teeth, for example, when Don Quixote, hurt by the loss of several molars caused by a stone thrown by a shepherd, tells Sancho:

«Te hago saber Sancho, que la boca sin muelas es como molino sin piedra y en mucho más se ha de estimar un diente que un diamante.»

«Be informed, Sancho, that a mouth without molars is like a mill without a stone, and a tooth must be valued high above diamonds."

We know that Miguel de Cervantes lost many teeth, this can be ascertained in the self-description he writes, where he shows his concern about his unenviable dentition:

Este que veis aquí, de rostro aguileño, de cabello castaño, frente lisa y desembarazada, de alegres ojos y de nariz corva, aunque bien proporcionada; las barbas de plata, que no ha veinte años que fueron de oro, los bigotes grandes, la boca pequeña, los dientes ni menudos ni crecidos, porque no tiene sino seis, y esos mal acondicionados y peor puestos, porque no tienen correspondencia los unos con los otros; llamase comúnmente Miguel de Cervantes Saavedra

(This person you see here, with aquiline face, brown hair, smooth and unencumbered brow, with happy eyes and curved although well proportioned nose, and silver beard, which not twenty years ago was golden, great whiskers and small mouth teeth poorly grown, because he only possessed six, and those six, poorly conditioned, and ever worse placed, because they lack correspondence among them can be commonly called Miguel de Cervantes Saavedra.)

In some of his sayings used in the novel, Cervantes uses dental terms such as what he makes Sancho say since he likes dental terms:

«Entre dos muelas cordales nunca pongas tus pulgares.»

(Between two wisdom teeth, never place your thumbs.)

Meaning you should never confront more powerful people, because you will always lose.

One of the characters of the Quixote is master Nicolas, the tooth pulling barber of the village where the illustrious nobleman lived. In fact, the wandering knight places a barber's pan on his head, as a helmet, evidencing thus the knowledge he possessed on the implements these professionals used.

The cult to Saint Apollonia was widely spread in the times of Cervantes; people suffering dental pain would pray to her for deliverance. In the second part of the novel, there is a reference to this saint, when one of the characters concerned about Don Quixote' $s$ madness, suggests to his servant that, on the way home, she should pray to Saint Apollonia, to which she answered:

«Eso fuera si mi amo lo hubiera de las muelas, pero no lo ha sino de los cascos.»

«That would be a fair idea if my master were a master of teeth, but he is not, he is a master of horse.»

Dental references included in the Quixote, and naturally, in other works by the author, also allude to dental cleansing, mentioning in several instances the moment in which an hidalgo, after eating, would pull a toothpick from his pocket, which could be gold or silver or simply wood, and would clean his dentition from stuck food remnants. At that time, this was not frowned upon and was socially well considered.

«El ingenioso Hidalgo Don Quijote de la Mancha», which doubtlessly is the first novel of the universal modern literature, and without question the most significant work of Spanish language of all times, is additionally an inexhaustible source of information on Spain of the end of the XV century and beginning of the XVI century. Idiomatic expressions, customs, environments, inter-personal ideas, beliefs, and for us, who are interested in the history of dentistry, it represents a real treasure.

\section{RECOMMENDED READINGS}

- del Valle-González A. La odonto-estomatología y el campo semántico de la boca en la vida y obra de Miguel de Cervantes Saavedra, aportaciones a la historia de la odontología de la época [Tesis doctoral]. Madrid, España: Departamento de Estomatología y Embriología Humana, Facultad de Ciencias de la Salud, Universidad Rey Juan Carlos; 2010.

- Esponda V, Aguilar L. Odontología del siglo XVI y la obra de Francisco Martínez del Castillo. En: Historia de la odontología inicio y desarrollo en México. México: Ed. Odontología Books; 2015.

- Rocha-Garfias V. Barberos y flebotomianos en el México Colonial. En: Historia de la odontología inicio y desarrollo en México. México: Ed. Odontología Books; 2015.

- Sanz-Serrulla J. La odontología en tiempos de don Quijote. Pontevedra, Punto de encuentro N 12 julio 2005.

Mailing address:

Martha Díaz Gómez

E-mail: diazkuri@gmail.com 